\title{
Legal Scholarship: Its Causes and Cure
}

\author{
Mark Tushnet ${ }^{\dagger}$
}

I suspect that symposia like this one are convened when it seems that something has gone wrong. ${ }^{1}$ I sense that the community of legal scholars is afflicted with a vague malaise, sometimes girded about by a pretentious complacency. ${ }^{2}$ Perhaps more important, that community has been operating for some years outside the main currents of significant intellectual activity. I cannot imagine, for example, an intellectual history of contemporary America in which legal thought would play an important part. There may of course be an erroneous premise implicit in the view that legal scholarship should be a central element of the serious intellectual discourse in this country. After all, law, like engineering, is an applied rather than pure endeavor, and no one expects engineers to participate in the intellectual life of the community. ${ }^{3}$ Yet, in the past, legal thought has been a component of important intellectual movements. Holmes and the Legal Realists played an important part in the story of American intellectual life in the earlier part of the twentieth century. ${ }^{4}$ In contrast, few of the various strands of contemporary thought are informed by legal scholarship. ${ }^{5}$ Even as prominent a contemporary legal scholar as Alexander Bickel, for example, warrants but two passing mentions in Peter Steinfels's examination of neoconservatism. ${ }^{B}$ The intellectual marginality of legal scholarship is all the more striking in light of the immense role that law plays in American society.?

My topic is that marginality. I contend that legal scholarship lies at the edges of serious intellectual activity because of the nature of

+ Professor of Law, University of Wisconsin.

1. Cf. Persons, The Wingspread Papers, 7 Rsv. AM. Hist. 447 (1979) (similar observation about papers from conference on intellectual history).

2. This impression is supported by such evidence as Professor Gilmore's elegant dyspepsia. G. Gilmore, The Ages of American Law (1977).

3. But see D. Hofstadter, Gödel, Escher, Bach: an Eternal Golden Braid (1979); T. Veslen, The Engineers and the Price System (1921).

4. See E. Purcell, The Crisis of Democratic Theory 74-76, 208 (1973); M. White, Soclal Thought in America: The Revolt Against Formalism $59-75$ (1949).

5. The exception might be Ronald Dworkin's role in mainline liberal thought. My comments below, see note 53 infra, suggest that he may be playing that role in his capacity as a philosopher rather than as a legal scholar.

6. P. Steinfels, The Neo-Conservatives 5, 6 (1979).

7. In the manner of Julia, I refrain from the obligatory citation to de Tocqueville. 
the legal scholar's enterprise. In part the problem derives from the dilemmas of professional education in an academic setting. Outside the law school, the main currents of twentieth-century intellectual life, encompassing Max Weber's work, phenomenology, structuralism, and much more, have been driven by scholars' efforts to confront and resolve the question of how an assertedly objective intellectual enterprise could be founded on what analysis showed was an unavoidably subjective base. ${ }^{8}$ For those who teach lawyers, however, the question is irrelevant. The conflict between objectivity and subjectivity is alien to their enterprise because no one believes that advocates are, or should be, objective. Thus, in their role as teachers of lawyers, legal scholars are not confronted by the most stimulating problem of twentieth-century intellectual life, and the pressures of professional education make it enormously difficult for them to escape from the constraints of that role.

But more than professionalism or the institutional structure of legal education is involved in the failure of the legal scholar's enterprise to confront the relationship between objectivity and subjectivity that has animated discussions outside the law. Legal scholars' professional endeavors may make them aware that legal rules have no objective content. They cannot bring this personal insight into their scholarly work, however, because their acceptance of fundamental principles of liberal political theory requires them to proceed as if legal rules do have objective content.

In its unadorned Hobbesian version, liberal theory begins with the premise that each of us desires as much as he or she can obtain. ${ }^{9}$ We are inclined to grasp everything within reach, without regard to the desires or interests of others. ${ }^{10}$ Nevertheless, we recognize that our desire for more will generally be thwarted in the war of all against all. Liberal theory proposes that we solve this dilemma by surrendering some of our autonomy to the state in exchange for security in our possessions. That surrender creates the new danger, however, that the state will exercise the power that we give it in ways that reduce both our possessions and our security. The rule of law is our protection against the state. The state must be constrained by rules that are independent of the desires of those charged with applying them in order to protect individual autonomy and prevent the state from

8. See H. Hughes, Consciousness and Society 15-17 (1958); H. Hughes, The Obstructed PATH 9-15 (1968).

9. See C. Macpherson, The Polmtical Theory of Possessive Individualism (1962).

10. Some exception may be made for close relatives. 
becoming another weapon for partisans to use in the general war. The acquiescence of individuals to the liberal rule of law depends upon their continued unshakable faith in its objectivity. Thus the conflict between objectivity and subjectivity cannot readily be confronted within the legal sphere without undermining liberal society itself. ${ }^{11}$

The fate of Legal Realism suggests the poignancy of the dilemmas that legal academics face. Most generally, Realism was a simple and unproblematic attack on the idea that the body of legal doctrine provided an objective basis for decisions in specific instances. Some Realists tried to escape this conclusion by emphasizing the law's relation to social policy, but that route only opened the legal system to even more basic challenges. First, policies are more obviously controversial than the apparently purely deductive arguments of case analysis. The appearance of objectivity could be maintained only by invoking policies of an extremely general sort. ${ }^{12}$ Second, neither those policies nor indeed any others could be brought to bear on a specific problem to provide a single solution. Policies, like precedents, could always be used to argue for contradictory results. Neither doctrine nor policy proved sufficient to satisfy the liberal premise that human behavior can be governed by rules that have some supra-individual content. As I will argue, legal scholars have ignored or rejected without serious analysis the disturbing implications of the Realist challenge to the objectivity of the rule of law.

I will develop this argument by examining the body of work now accepted as legal scholarship. I rely in part on a survey of law review articles, ${ }^{13}$ but my own observations as a member of the aca-

11. See R. Unger, KNowledge and Polmtics (1975).

12. The work of Lasswell and McDougal is the most obvious example.

13. The details of the survey will be provided on request. Briefly, I examined the signed articles published in the two most recently completed volumes of the following law reviews: Columbia, California, Duke, Michigan, New York University, Pennsylvania, Texas, and Virginia. I chose those law reviews because they are published at relatively elite schools in the hierarchy of legal education. I excluded the schools at the top of the hierarchy-Chicago, Harvard, Stanford, and Yale-because, in my judgment, there is a break in the stratification system between the two groups of schools. That judgment could be confirmed by an examination of the circulation of faculty members, which I suspect would show that faculty circulate within each stratum and that the most elite schools accept faculty members from the less elite schools, but faculty from the more elite schools do not move to the less elite schools.

I excluded student work from the analysis because it is so heavily weighted toward what I describe as the first form of scholarship that its inclusion would distort any rough statistical judgments in a highly misleading way. I also note here, but do not analyze, the phenomenon of privileged access to law reviews. Such privileged access has three forms. A scholar at a more elite school can almost automatically get an article published 
demic community form a more important basis for the argument. In this inquiry, I treat myself as an informant. ${ }^{14}$

Legal scholarship today has three forms, for which I have been unable to develop non-invidious labels. The first is traditional legal advocacy, the second is advocacy augmented with concepts drawn from nonlegal fields of thought, and the third is the study of law as a phenomenon. The third form of scholarship is qualitatively different from the first two; roughly, the first two are normative enterprises, while the third is a positive one. I will argue that the first two forms seek to establish the proper or best legal rule. In doing so, they make claims to objectivity that are contradicted by their inherent partisanship. The third form attempts to escape this dilemma. If it can be done at all, the third form can be done only at the most elite schools, where professional pressures are weakest. Such schools, however, maintain their elite position in part by their role in the professional enterprise. Under those circumstances, it is not surprising that legal scholars have, except in isolated cases, been unable to connect their work to the basic themes of contemporary intellectual life.

Most of the articles published as legal scholarship constitute what I have called traditional legal advocacy. ${ }^{15}$ These articles most starkly reflect the impact of professional demands upon the academy. Practicing lawyers and others who attempt to affect public policy through law are busy people. Law reviews give them some convenient research tools, through articles that present the arguments for one position or another and explain how the arguments for contrary positions can be rebutted. The structure of such articles makes it clear that they contribute little to reducing the marginality of legal scholarship.

The standard traditional advocacy article has two variants: the case analysis and the policy prescription. The case analysis argues that, when one looks at the cases, certain conclusions follow. For example, one recent article deals with the constitutionality of statutes that limit

in a review at a less elite school. Ceremonial addresses in formal lecture series will almost always be published. These forms of privileged access are infrequently used. Much more significant is the fact that law reviews will almost always publish the work of scholars on the faculties at their own schools.

14. I should note that my primary informant, myself, finds himself on the margins of the legal academic world. The Law School at the University of Wisconsin has attempted to take a path that is quite different from those followed by other schools. In addition, my personal sense of marginality, though qualified by such things as my participation in this symposium, is nonetheless real. I observe, however, that with the exception of Professor Posner, who is obviously a special case, I am the only participant presenting a major paper who has not taught at Harvard or Yale (or both).

15. In the survey, between $60 \%$ and $70 \%$ of the articles were of this form. 
the ability of a defendant accused of rape to examine aspects of the victim's history. ${ }^{16}$ It discusses the Supreme Court's interpretation of the confrontation clause of the Sixth Amendment and concludes that some of the statutory limitations are unconstitutional. The authors treat their conclusions as deductions from the Constitution, but the legacy of Realism makes that impossible for serious readers to accept. ${ }^{17}$ Instead, the article must be read, as I suspect it was intended to be read, as a research aid for lawyers who defend persons accused of rape, and for the judges before whom those lawyers appear. ${ }^{18}$

The policy prescription identifies some goal that the author thinks ought to be pursued. It uses common sense and a rough-and-ready folk sociology or economics to sketch how to achieve the objective. Unlike the case analysis, the policy prescription tends to be relatively open about the act of choice inherent in selecting a goal. Like the case analysis, however, the policy prescription places the act of choice in a frame designed to obscure its subjective and essentially arbitrary character. The choice is made under the guise of identifying a problem to be solved. "Everyone knows," for example, that corporations' boards of directors are unresponsive to the interests of some of those whose lives are affected by their decisions. The solution of that "problem" can be discovered by applying common sense notions about representation and responsiveness. ${ }^{10}$ The policy prescription usually ends with a suggestion about how the policy could be enacted into law and is therefore the ideal legislative history.

Despite intended appearances to the contrary, both case analysis and policy prescription rely on choices that are not only subjective but controversial. The dialogue they promote is often intellectually

16. Tanford \& Bocchino, Rape Victim Shield Laws and the Sixth Amendment, 128 U. PA. L. REv. 544 (1980).

17. In this article, I assume that Realism has carried the day to the extent described. I defend that assumption elsewhere. See Tushnet, Post-Realist Legal Scholarship, 1981 W'Is, L. REV. 1383.

18. One variation, case analysis carried to its highest level, lies in the transitional zone between the two forms. Although there are a few examples from other areas, see e.g., Westen, Confrontation and Compulsory Process: A Unified Theory of Evidence for Criminal Cases, 91 HARv. L. REv. 567 (1978); Westen \& Lehman, Is There Life for Erie After the Death of Diversity? 78 Mrch. $\mathrm{L}$. REv. 311 (1980), the best example is the scholastic debate among proponents of various types of interest analysis that allegedly elucidate conflicts of law. An outsider to the discussion finds it bizarre that elaborate competing structures of analysis have been erected on the basis of policies so general that, one would have thought, they could not possibly dictate the kinds of results that interest analysts claim for them. See Kay, The Use of Comparative Impairment to Resolve True Conflicts: An Evaluation of the California Experience, 68 CALIF. L. REv. 577 (1980).

19. See, e.g.. C. Stone, Where the LAW Ends (1975); R. NAder, M. Green, \& J. Seligman, Taming the Gunt Corporation (1976). 
sterile, ${ }^{20}$ because someone else can simply choose another goal and use the same type of analysis to come to the opposite conclusion. An article that goes with the crooks is followed by one that goes with the prosecutors; ${ }^{21}$ one that says that corporate responsibility is a problem is answered by one that says that everything is hunky-dory.

The most intriguing question that remains is why a frame of objectivity is placed around the discussions that $I$ have described. Legal Realism produced the insight that case analysis cannot generate objective answers to legal problems. Bringing concerns about policy to the fore, which some lawyers saw as the only way to save the system, has turned out to be equally manipulable. What is puzzling is the insissistence of authors of even the most advocacy-oriented articles that they do have the objective answers. The objective posture may be just another technique of advocacy. "I like it" is not a very good argument, but "the Constitution says so," stated with appropriate emphasis and in a sincere tone, can be persuasive. I will return to the possibility that an objective posture is good advocacy because the norm of objectivity is an essential element of liberal political theory after discussing the other forms of legal scholarship.

The second form of scholarship, advocacy augmented with concepts from other fields, is a reaction to the failings of the first form of scholarship. It accepts the conclusion that solutions to legal problems cannot be found within the framework of what we traditionally had thought of as law, defined here to include both legal reasoning and common sense. Nevertheless, it retains the hope of reaching objectively defensible results by relying on ideas that are drawn from fields in which scholars' partisanship is not as apparent. Unfortunately, the hope is bound to be disappointed because problems of objectivity and subjectivity infect other fields as pervasively as they do law. The ultimate effect is only to conceal the point at which subjective choice is inserted into the analysis. Indeed, one measure of the quality of scholarship of the second form is the cleverness with which that point is obscured.

20. When those who disagree on proximate goals agree on ultimate ends, the sterility of their discussions results from the ability of sophisticated analysis to show how accomplishing either proximate goal will promote the ultimate end. See note 24 infra.

21. In fact, more articles supporting crooks are written, largely because of the sociology of legal education. With the expansion of clinical programs in law schools, significant numbers of people with academic interests were hired to staff those programs. Whether on tenure tracks or not, the new faculty members were attracted to writing for law reviews and, because the largest group in their clientele consisted of people accused of committing crime, they were attracted to the pro-crook position. The predominance of that approach is enhanced by the general phenomenon that exists in higher education of younger faculty members writing more than older ones. 
The second form of scholarship has two variants, doctrinal and policy analysis, which parallel the variants found in the first form. Doctrinal analysis of the second form, like traditional case analysis, invokes a very general, allegedly formal, guiding principle and claims to be able to derive determinate solutions to particular legal problems by application of that principle. For case analysis, the frame of reference is the logical and aesthetic requirements of traditional legal reasoning. There are two dominant versions of doctrinal analysis of the second form, and each has its own lodestar. The school of normative law and economics, Chicago style, looks to allocative efficiency. Moral philosophy, meanwhile, looks to conformity with Natural Law.

I will begin with the Chicago School, whose difficulties are twofold. First, the scientistic tendencies of its approach have led its adherents to a hard-line methodological positivism. The Chicago version of positivism makes it clear that scientistic analysis must be sharply distinguished from normative recommendations and that such recommendations depend on a choice that must be made on some nonscientistic basis. ${ }^{22}$ The closer an author making recommendations comes to the Chicago paradigm, the more that author must explicitly admit that efficiency is a subjective preference rather than a selfevident formal axiom. That admission, in turn, defeats the goal of looking for objectively defensible results in other fields.

Second, the scientistic pretensions of the Chicago School have led at least its lesser adherents to make claims about the results of their approach that are indefensible even within its own frame of reference. The fact of the matter is that the Chicago approach is infected by the same problem of indeterminacy that the Realists identified in traditional legal scholarship. The Chicago model of economic analysis can explain how any policy can achieve whatever goal we choose to pursue. ${ }^{23}$ Warranties of habitability, for example, both do and do not promote efficiency. ${ }^{24}$ This apparently curious outcome may be a result of the state of the art or, as I suspect, a result of internal incon-

22. Posner, Some Uses and Abuses of Economics in Law, 46 U. CHr. L. REv. 281, 28487 (1979) (distinguishing positive from normative economics).

23. See Heller, The Importance of Normative Decision-Making: The Limitations of Legal Economics as a Basis for Liberal Jurisprudence-As Illustrated by the Regulation of Vacation Home Development, 1976 Wis. L. REv. 385.

24. The arguments are summarized in Markovits, The Distributive Impact, Allocative Efficiency, and Overall Desirability of Ideal Housing Codes: Some Theoretical Clarifications, 89 HARv. L. RIv. 1815 (1976) (describing conditions under which allocative efficiency is promoted by housing codes). Efficiency, in the models relied on, is defined only in terms of a partial equilibrium. They do not analyze general equilibrium implications. See Rizzo, The Mirage of Efficiency, 8 Horstra L. REv. 641 (1980). 
sistencies in the epistemology that underlies the field, but in either case the immediate problem is the use of unsupported abstraction. When the scientistic pretensions of the Chicago approach are greatest, the analyst follows the model of the physical sciences and adopts a large number of simplifying assumptions. The purified system is then analyzed, and predictions and explanations are generated. The real world, however, is necessarily more complex than the purified system. It may be true, for example, that economists can generate apparently interesting conclusions by assuming that corporate managers respond appropriately and exclusively to profit-oriented incentives. Indeed, they may even be able to explain outcomes in the real world by assuming that managers so respond, although that is more troublesome because of severe measurement problems. ${ }^{25}$ But the normative claim that legal regulation should try to affect only profit-oriented incentives simply does not follow. ${ }^{26}$

Similar problems beset the attempt to rely on moral philosophy as a source of legal insight. If economics challenges common sense with Science, the brand of moral philosophy now most in vogue elevates common sense, or at least the common sense of the liberal left, to Natural Law. Contemporary moral philosophy has the rhetorical advantage over Chicago School analysis of the chastening of style ${ }^{27}$ that ordinary language philosophy has effected. Indeed, moral philosophers tell charming fairy tales about the legal system. These fairy tales, however, like the economists' stories, rest on extraordinarily severe abstractions from reality. Professor Dworkin, for example, invents a superhuman judge he calls Hercules; ${ }^{28}$ scholars following his trail are forced to distinguish between situations in which a principle has a relative weight of $51 \%$ and those in which its weight is $49 \% .^{28}$ Another favorite tactic is to hypothesize a legal system that contains only one rule that bears on a problem and then show how contemporary moral

25. For an example of the gap between theoretical simplification and available evidence, see Landes \& Posner, Legal Change, Judicial Behavior, and the Diversity Jurisdiction, 9 J. LEGAL STUD. 367 (1980) (available empirical evidence provides limited support for economic theory of judicial behavior).

26. For an exchange that clarified the point, see Harris \& Sullivan, Passing on the Monopoly Overcharge: $A$ Response to Landes and Posner, 128 U. PA. L. REv. 1280 (1980), and Landes \& Posner, The Economics of Passing On: A Reply to Harris and Sullivan, 128 U. PA. L. REv. 1274 (1980).

27. I borrow the phrase from Edmund Wilson. See E. Wilson, PATriotic Gore 635-742

(1962) ("The Chastening of American Prose Style").

28. R. Dworkin, Taking Rights Seriously 105-06 (1977).

29. D'Amato, Judicial Legislation, 1 CARDOzo L. REV. 63, 82-84 (1979). 
philosophy yields clear results in that system. ${ }^{30}$ As in the case of economic analysis, discussion of these abstractions has some metaphorical force. But real decisionmakers are weaker than Hercules and real legal systems have more than one rule. Moral philosophy, in its present state, can only rely on objective values that are so abstract that they cannot provide normative guidance in real cases. A theory of justice in a world with serious imperfections is undeveloped in the literature and might help. I would bet, however, that a philosopher's theory of second best would establish that moral philosophy alone must remain insufficient.

The failure of moral philosophy to solve real-world problems emphasizes once more the nature of the legal scholar's difficulty. We must keep in mind the reason for recourse to other fields. Realism showed that subjectivity and indeterminacy resulted when analysis was confined to traditional legal discourse. Because the rule of law requires objectivity and determinacy, scholars looked elsewhere to save the rule of law. I need not argue for my purposes that moral philosophy is subjective. ${ }^{31}$ The truly pressing, and endemic, difficulty is indeterminacy. ${ }^{32}$ The most dramatic example of this difficulty is the one that I believe made moral philosophy seem attractive. The Supreme Court's abortion cases could only be defended on philosophical grounds. Yet the controversy on the issue among professional philosophers is as substantial as that in the political arena. The lawyer's normative problems are left as unresolved by the invocation of moral philosophy as they are by the invocation of economics. Moral philosophers and economists are divided into the same camps that mere lawyers are, and "respect for persons" or "efficiency" turn out to be translations into esoteric language of "my client wants it." The nonlegal disciplines, as I suspect real economists or philosophers could have told us from the start, were as partisan as law and, therefore, could not provide the support that legal scholars sought. Both Chicago School economics and moral philosophy, when they are sub-

30. Richards, The Theory of Adjudication and the Task of the Great Judge, 1 Carbozo L. REv. 171, 199-200 (1979). But see Regan, Rewriting Roe v. Wade, 77 Mich. L. REv. 1569 (1979) (performing the Herculean task).

31. I do find it somewhat suspicious, though, that the liberal left of the Democratic Party and not, for example, the Swedish Social Democrats, has a near monopoly on Natural Law.

32. There is another difficulty that is linked more directly to the theory of second best. Even if moral philosophers had the ultimate answers, it is not obvious that those answers would be close enough to contemporary American society for us to enact them in the incremental manner characteristic of American lawmaking; nor is it clear that direct moves in the direction of those answers would be the best steps to take in order to reach them. See Tushnet, Dia-Tribe (Book Review), 78 Mich. L. REv. 694, 708-09 (1980). 
jected to critical scrutiny, accomplish little more than a certain intimidation of those of us less versed in particular scholarly fields. Professional incentives that are already operating will readily eliminate even that effect.

As in traditional legal scholarship, policy analysis is the alternative to doctrinal analysis in the second form of legal scholarship. In traditional policy analysis, common sense is used both to select a goal and to determine how to achieve it. The second form of policy analysis does not, at least openly, dispute the goal. Rather, adopting the strategy of expert analysis in other fields, it questions the common sense prescription for achieving that goal. This analysis takes one of two lines. Sometimes it argues that the common sense route may not get us to the goal as effectively as some other route. ${ }^{33}$ For example, when greater corporate responsibility is the goal, the analysis draws on economic theory to show that such responsibility is maximized by market, rather than political, processes. ${ }^{34}$ Alternatively, it may examine the side-effects of the common-sense route, showing that, in a world as perverse as ours, following that route will produce a conflict, not with the original goal, but with some other desirable objective. Eliminating discrimination based on gender, for example, will require imposing and enforcing limits on the hours that professional men can work. ${ }^{35}$ The next step of this line of analysis is to search for a way to reach the original goal, subject to the constraint that in doing so we do not intrude too much on other values. At the end of the line, of course, the policy analyst all too often concludes that, in light of all the constraints, we really cannot reach the original goal at all.

Sophisticated policy analysis of the type I have just described expresses what I call the "life is just a bowl of Jello" point of view. ${ }^{36}$ According to that view, the world is so complex that if you push at

33. See generally R. Posner, Economic ANalysis of LAw (2d ed. 197') (discussing efficiency of law in numerous fields).

34. See, e.g., Engel, An Approach to Corporate Social Responsibility, 32 STAN. L. REv. 1 (1979); Winter, State Law, Shareholder Protection, and the Theory of the Corporation, 6 J. LeGal STUd. 251 (1977).

35. Powers, Sex Segregation and the Ambivalent Directions of Sex Discrimination Law, 1979 WIS. L. REv. 55, 105-07.

36. See, e.g., Graetz, Implementing a Progressive Consumption Tax, 92 Harv. L. Rev. 1575 (1979) (progressive consumption tax provides theoretically meritorious means of assessing tax liability but practical and political costs ensure its unworkability); Kirp \& Robyn, Pregnancy, Justice and the Justices, 57 TEx. L. REv. 947 (1979) (question of pregnancy benefits must be addressed only after considering costs and benefits to workers and families); Schuck, The Graying of Civil Rights Law: The Age Discrimination Act of 1975, 89 YALE L.J. 27 (1979) (congressional failure to specify adequately the objectives of the Age Discrimination Act moves policy debate into court). 
one point where you perceive a problem, the most that you can accomplish is to cause the problem to migrate to some other area over which, you hope, someone else has jurisdiction. ${ }^{37}$ If other approaches to legal scholarship end up losing their power when they are shown to be indeterminate, the bowl-of-Jello approach tries to escape this trap by triumphantly concluding that there are no good answers. This inherently conservative conclusion ${ }^{38}$ fails as a significant intellectual achievement, however, because of the same limitations of professional orientation and liberal imagination that plague the other approaches. The evidence it relies upon establishes at most, after all, that incremental reasoned interventions in a complex situation are unlikely to produce satisfactory results, because incremental intervention fails to deal with surrounding areas into which problems will migrate. But more substantial reasoned interventions may work. For example, the resistance of bureaucracies to change is a typical ground for skepticism about intervention. It may be that if we truly desire change, we will have to do away with bureaucracy. The aim of policy analysis, however, is to make recommendations to policymakers. Members of an existing system of government will only take seriousiy recommendations for incremental change within the limits of liberal politics. The utopian thinking needed to escape from the bowl of Jello is not likely to be done by those whose immediate audience consists of contemporary policymakers, and who are themselves committed to the assumptions of liberal theory. ${ }^{39}$

37. See, e.g., Alschuler, Sentencing Reform and Prosecutorial Power: $A$ Critique of Recent Proposals for "Fixed" and "Presumptive" Sentencing, 126 U. PA. L. REV. 550 (1978) (criminal justice is closed system in which discretion can be reallocated but not reduced).

38. The bowl-of-Jello approach proves to be inherently conservative because it leads to the conclusion that, in the absence of good alternatives, the statur quo ought to be retained. Another possible conclusion is available, which I call Burkeanism, but it proves to be unavailing. The Burkean says that whatever choice is made by the system is legitimate and may even contain some hidden wisdom. Although Burkeanism is, on this level at least, coherent, it will not help the scholar in the professionally oriented attempt to advise judges and policymakers. The reactionary can at least say that change is bad. The serious Burkean has to say that change is all right if the system changes, but that is not terribly useful when the issue is whether a change should be made.

39. Resistance to utopianism arises in part from the liberal view that links utopian thinking to the social catastrophes of the twentieth century. Aside from overestimating the importance of thought in transforming the world, this view assumes that only pragmatic tinkerers can learn from experience. Utopians concerned about bureaucracy speculate not about perfecting massive, national bureaucracies, for example, but about constructing alliances among small scale, intensely local activities. See, e.g., J. MaNSBrwas, Beyond Adversary Democracy (1980). This perspective is what gives such power to the otherwise quite different visions of Roberto Unger and Robert Nozick. Moreover, as I suggest below, a utopian approach of this type may be the only way to resolve some of the problems inherent in the liberal theory of law and society. See p. 1223 infra. 
I have argued that the marginality of contemporary legal scholarship results from the combined pressures of professionalism, the desire to support the rule of law, and the attempt to escape the implications of Realism. I first appreciated that something was at stake in those pressures when, after I had made what I regarded as rather mild and standard Realist criticisms of a doctrinal proposal, ${ }^{40} \mathrm{I}$ was called a power-hungry anarchist. ${ }^{41}$ I realize, of course, that nobody really likes to be criticized and I might have discounted, although not disavowed, the epithet, except that I began noticing that similar, hostile rejections of the implications of Realism were expressed elsewhere. The mild version is the definitional stop: partisanship is a defining characteristic of the enterprise and that's the end of it. ${ }^{42}$ One can hardly argue with definitions. But that particular definition affirms the intellectual marginality of legal scholarship and excludes from the canon some work done by people who have reputations as important legal scholars.

Concern over Realism's legacy seems to recur at generational intervals. The recent expressions echo charges made in the 1940s that Holmes's anticipation of Realism led inexorably to the intellectual defense of totalitarianism. ${ }^{48}$ Professor Bickel's discussion in The Least Dangerous Branch, twenty years later, remains the most revealing. In a chapter whose first citation is to the article by Professor Gilmore from which I drew my title, Professor Bickel discusses "the NeoRealists [and the] Nihilists." $14 \mathrm{He}$ argues that the original Realist position of the 1920s and '30s, insofar as it exploded the claim that the text of the Constitution was a self-evident document, was a reasonable and positive contribution. The danger lay in the work of some of the successors to the Realists who, engaging in "overkill,"45 asserted the impossibility of any principled decisionmaking and became purely result-oriented.48 For Bickel, the only proper function of judicial review was "to evolve and apply ... fundamental reasons of principle

40. Tushnet, The Sociology of Article III: A Response to Professor Brilmayer, 93 Harv. L. REv. 1698, 1699.705 (1980).

41. Brilmayer, A Reply, 93 Harv. L. Rev. 1727, $1728-29$ n.16, $1729-30$ (1980).

42. See, e.g., Monaghan, Taking Supreme Court Opinions Seriously, 39 MD. L. REv. 1, 13-14, $25(1979)$ (stating that the premises of our system assume that principled opinions are achievable).

43. See White, The Rise and Fall of Justice Holmes, 39 U. CHI. L. REV. 51 (1971).

44. A. Bigkel, The Least Dangerous Branch 74 n.1, 75-84 (1962).

45. Id. at 75 .

46. "The final fruit of nea-realism," he wrote, ". . . is a genial, nihilistic attitude of coexistence with the Court and its work, along with a complete lack of interest in the process by which the work is achieved, or in the proper role of that process in a democratic society." Id. at 81. 
on which to base men's actions, and which should cut across men's uncontrolled instincts and interests." 47 The neo-realist's view that judges did not engage in this principled discourse, but only did "what they like[d]" 48 was pernicious, and was no less so if it was sometimes true.

[I]f the estimate of reality on which it feeds is in any degree correct, then reality must be changed to exactly that degree. The sin is mortal, because it propagates a self-validating picture of reality. If men are told complacently enough that this is how things are, they will become accustomed to it and accept it. And in the end this is how things will be. ${ }^{9}$

Professor Bickel's strategy for changing the "neo-realists' " reality avoided, if barely, the definitional stop. As Professor Ely has noted, however, Bickel's later work demonstrated his understanding that his initial strategy needed substantial development, probably in directions different from those suggested by the Wechslerian emphasis on principles or the philosophical emphasis on fundamentals. ${ }^{50}$ More important, Professor Bickel, like those Realists he admired, thought that problems of subjectivity were merely difficulties encountered in executing a program grounded in the rule of law. Since the Realists wrote, we have come to understand that the problems they described arose from the concept of rules and from the characteristics of language itself.s1

Professor Bickel's adversaries deserved his criticism that they were expounding "cynicism pure and simple" 52 because they attempted to maintain a defense of the rule of law while simultaneously pushing Realism to its far boundaries. They understood that liberal political theory provided no explanation for why people, upon assuming the role of judge, could suddenly become moved by preferences that transcended the merely personal. They knew as well that the process of judicial decision was as subjective as other more obviously political activities. What left them open to the charge of cynicism was their continued adherence to some tenets of liberal theory coupled with their failure to appreciate that, by translating the subjectivity of pref-

47. Id. at 82.

48. Id. at 84 .

49. Id.

50. J. Ely, Democracy ANd Distrust 71.72 (1980).

51. The fancy citation for this is 1 . Wittgenstein, PhiLosophical Investigations (1953).

52. A. BiakeI, supra note 44 , at 84 . 
erence from the legislative to the judicial context, they had undermined the only defense liberal theory had against tyranny. ${ }^{53}$

There are two possible responses to Professor Bickel's critique. The first is to deny the force of Realism by attempting to confine its analysis of rules, through moves such as the appeal to neutral principles. That attempt, as we have seen, is intellectually dishonest. Bickel's struggle to work out a Burkean approach to law, which all agree he did not completely realize, demonstrates both the depth of his understanding and the inadequacies of the first two forms of scholarship. The second response is to discuss law without assuming that liberalism's reliance on the rule of law solves the problem of subjectivity. Professor Bickel showed the way by counterposing "personal preference and personal power" 4 to "fundamental reasons ... which should cut acruss men's uncontrolled instincts and interests." Legal scholars need not assume that twentieth-century American society approximates the ideal liberal state, and though they may agree that the rule of law is a necessary component of such a state, they need not assume that the preconditions of liberalism exist in contemporary society. To the extent it brackets but does not reject liberal political theory, the second response to Bickel's critique should produce a program of research concerning the social conditions necessary for the realization of the rule of law. To the extent that it does reject liberal theory, the second response should produce a program of research on the conditions under which justice, defined in terms other than the rule of law, can be achieved. ${ }^{\text {je }}$

The third form of contemporary legal scholarship-the study of law as a phenomenon-comes closest to these programs of research; it brackets liberal theory by treating law as a phenomenon. In adopting that strategy, however, the third form abandons the professional orientation of the other forms of scholarship and places its practitioners under severe pressure. That pressure can be resisted occasionally only at the most elite institutions or elsewhere only under

53. See R. UNGER, supra note 11, at 83-97. Although Bickel addressed the issue of the rule of law in the context of constitutional law and judicial review, it arises in private law as well. See, e.g., Kennedy, Form and Substance in Private Law Adjudication, 89 HaRv. L. REv. 1685 (1976).

54. A. BICkEL, supra note 44 , at 80 .

55. Id. at 82.

56. Realism is a powerful intellectual force, in part, because it produced those research programs directly, though the Realists themselves were far more sophisticated in their analysis of the concept of the rule of law than they were in this branch of their project. For a more extended discussion, see Tushnet, Post-Realist Legal Scholarship, 15 J. Soc. PuB. Tcrrs. L. 20, 28-30 (1980). 
unusual circumstances. The work produced under those conditions is also likely to be seen as marginal to legal scholarship, and thus legal scholarship's own marginality will persist. ${ }^{57}$

Unfortunately, much of the work in the third form of scholarship only extends approaches that are taken in the second form. ${ }^{58}$ The dominant strand of positive analysis of law, not surprisingly, is the economics-of-law approach. I need not recapitulate the various critiques of this approach, ${ }^{59}$ some of which I suggested in discussing its normative cousin. Positive analysis along Chicago lines has claimed that the classical common law promoted allocative efficiency. One of the explanations offered for why this should be so is that the legal system somehow tends toward a realization of moral truth or, to modify Emile Coue's autosuggestive aphorism, that every day in every way the common law is getting better and better. Professor Priest tried to describe the mechanism through which such Coueism is effected. ${ }^{\circ 0}$ But when Professor Priest reduced the abstractness of his model by adding a single new variable that took account of the pos-

57. Proselytizers for the third form sometimes argue that it is professionally valuable. The analytic schemes they develop, they say, provide useful ways of organizing a complex body of information, give insights into the kinds of arguments decisionmakers find attractive, and so on. The professionalist defense of the third form of scholarship is probably valid, but in a rather restricted sense. Someone who is able to analyze cases and policies well, as in the first form of scholarship, and who can augment that ability by drawing on work done in other fields, 25 in the second form, is likely to be a better lawyer for being able, in addition, to step back from the whole enterprise to see it as an event in the world. Unfortunately, few professionals have enough talent to master the first two forms and then study the third. Selectivity in law school admissions means that the third form of scholarship will be professionally valuable to a significant concentration of students only at the most elite institutions. Although there are inevitably a few students at every law school who could profit from the third form's approaches, the absence of a group of sufficient size is likely to create pressures at the less elite schools against following the model used by some scholars at the more elite schools. Although this process may well create the conditions for linking elite scholarship to broader intellectual currents, it also confines such scholarship to clite institutions. Under those circumstances, those who produce scholarship of the third form may be seen less as lawyers than as social theorists, economists, or whatever, and their work may not be seen as "legal" scholarship at all.

58. On the moral philosophy front, Professor Fried recently suggested that we can examine law as a moral science. Fried, The Laws of Change: The Cunning of Reason in Moral and Legal History, 9 J. Legnl STUD. 335 (1980). I have been told that the suggestion was not made entirely seriously and, in any event, I cannot devote much attention to it because there are no clear examples of the enterprise.

59. See, e.g., An Introduction to Post-KeYnesinn Economics (A. Eichner ed. 1979); Time, UnCertainty, And Disequilibrium (M. Rizzo ed. 1979); Komesar, In Search of $a$ General Approach to Legal Analysis: A Comparative Institutional Alternative (forthcoming Mrch. L. REv. (1981)); Markovits, A Basic Structure for Microeconomic Policy Analysis in Our Worse-Than-Second-Best World: 1 Proposal and Related Critique of the Chicago Approach to the Study of Law and Economics, 1975 Wis. L. REv. 950.

60. Priest, The Common Law Process and the Selection of Efficient Rules, $6 \mathrm{~J}$. LEGAI STUd. 65 (1977). 
sibility that cases could be settled before judgment, his earlier result disappeared. ${ }^{61}$

In any case, what Chicagoans call allocative efficiency can equally well be called capitalist accumulation ${ }^{62}$ or the redistribution of wealth from poor to rich or economic development. ${ }^{63}$ Perhaps more to the point, the common law can at most be consistent with one construction of allocative efficiency, even within the neoclassical tradition of economics. It might not be consistent with other constructions, and the premises of positive analysis do not provide the basis for choosing between those constructions.

Positive economic analysis of law has generated some useful insights, although I suspect that Chicagoans will take my specification of those insights as a backhanded compliment. A major contribution, for example, is the Chicago School emphasis on invisible hand mechanisms, as opposed to the conscious choices of participants, as a means of explaining activities in the legal system. That contribution has unfortunately been embedded in more specific and less defensible claims, and attacks on the specific claims may discredit the more important general point. In light of all the problems inherent in positive economic analysis of law, I confess to being unable to rid myself of the sense that, although it has drawn attention to the subtle operation of power, we would know more about law had the same energy and intelligence been devoted to understanding Middlemarch ${ }^{64}$ and The Executioner's Song. ${ }^{\circ 5}$

The most productive course that the third form of scholarship could take probably would involve social theory. Social theory in the twentieth century has revolved around efforts to resolve what have been conceived of as epistemological problems of social knowledge. The problems arise as claims to objective knowledge are confronted with the reality that knowledge is produced by individuals located inextricably within the arena about which they are said to have knowledge. Marxism, by insisting that all knowledge is a social product and thus that knowledge can have no transcendent validity, generates the central position to which all theories of knowledge respond.

61. Priest, Selective Characteristics of Litigation, 9 J. Legal STud. 399, 400-01 (1980). Priest's general conclusion in this article-that the cases most likely to be resolved by judges are those whose decisions are least likely to be predicted by any explanatory theory-only confirms, if in a limited way, the indeterminacy of the rule of law.

62. See M. HoRwitz, The Transformation of American Law xvi (1977).

63. See O. Handin \& M. Handin, Commonwealth $53-92$ (1947).

64. G. Eliot, Middlemarcir (1871-72).

65. N. MAILER, The Executioner's SONg (1979). 
There is a direct line, intellectual and institutional, from Realism to the use of social theory in analyzing law. ${ }^{68}$ Such work, however, has never had more than the most tenuous toe-hold in law schools. In part, the reasons are again institutional. The point of entry for the confrontation of objectivity and subjectivity would have been Realism in the 1930s. But the cooptive power of the New Deal in the center and Communist labor-organizing efforts on the left was great enough to channel young lawyers, who, after all, had been trained as professionals, away from the issues with which academics in related fields were concerned. Further, legal academia had fewer positions and, I suspect, was more strictly hierarchical, than other academic fields in which a few unorthodox scholars could find lodging at small liberal arts colleges. ${ }^{67}$

More recent institutional history is also relevant. Perhaps the best example comes from Yale Law School, which has been the leading institution dabbling in the use of social theory in analyzing law since Realism came of age. During the 1960s, a period that Professor Abraham Goldstein has called the "Dark Ages" of Yale,"8 a series of decisions not to grant tenure to certain members of the faculty were made. When the full story is told, these decisions will be linked to complex questions of academic and external politics. But there is a broader point to be made. Yale, as a professional school, is subject to the professional pressures I discussed earlier. Its ability to resist those pressures depends on its maintaining its elite position. A number of strategies are available. Chicago, for example, has achieved its position by the single-minded pursuit of one specialty. Yale's strategy has been more subtle. Its goal has been to keep a few steps-or more mundanely, two to five years-ahead of the pack by having scholars on the faculty who are now doing what many more people will be doing in a few years. This strategy, however, has significant implications for hiring and tenure policies. Tenure can be given only to those who can switch specialties before the trend line changes direction. But learning social theory is a difficult enterprise. Few law stu-

66. See J. Schlegel, Institutionalizing the Study of Law and Society: The Law Schools (June 20-28, 1980) (unpublished paper presented at the 1980 Annual Meeting of the Law and Society Association) (on file with Yale Law Journal).

67. For a collection of essays that makes this point in a limited, and distinguishable, context, see The Intellectual Migration (D. Fleming \& B. Bailyn eds. 1969) (effect of European immigrants on American intellectual life). The book's list of " 300 Notable Emigres," id. at 675-718, includes five scholars with significant affiliations with law schools and reveals the wide range of institutions that initially absorbed the emigres.

68. Without challenging the characterization, I must note that it is less clear to me than it apparently is to Professor Goldstein who were the monks and who the barbarians. 
dents can absorb enough social theory to become specialists in it at the same time that they acquire the elite credentials as lawyers or legal scholars who are more than technicians. Those who master social theory are, for emotional and intellectual reasons, less likely than others to be willing or able to convert to other activities should the institutional need arise, and are, therefore, not attractive candidates for tenure. Because the conditions for the integration of social theory and law are even less favorable elsewhere than they are at Yale and other elite institutions, the tenuous position of this type of legal scholarship will certainly continue.

More important than all the institutional forces I have described, however, there are certain intellectual reasons for the failure of social theory to emerge in legal scholarship. Sociologists and historians can raise and face problems of objectivity and subjectivity, difficult as they may be, without threatening the foundations of their enterprises because they can reconstruct their fields from the smallest units of human interaction, as phenomenologists and ethnomethodologists have done. ${ }^{69}$ As $I$ have argued, that is not true of legal scholars in a liberal society. Some defects in the Realists' early formulations were also influential. Because the Realists were heirs of the Progressive tradition in historiography, they tended to attribute outcomes in the legal system to the self-conscious and usually self-serving decisions of actors in the system. Although they understood that their analysis of legal rules led inevitably to an analysis of the operation of power, they reduced power to the self-interested actions of a few wilful men or to pure subjectivity. Debunking the pretensions of those who say they are motivated only by the public interest is frequently valuable, but it is almost always an incomplete account of the exercise of power.

The institutional and intellectual barriers to the integration of legal and social theory are substantial enough that it is unlikely that legal scholarship will soon be incorporated into the mainstream of intellectual life. There are several responses to the intelfectual marginality of legal scholarship. First, one could simply give up; the rewards accruing to unconventional work and the merits of conventional work are both too small. Second, one might try to overcome the barriers I have mentioned. Abandoning the liberal theory of law, one might deny law its privileged status as a device by which to reconcile subjectivity and objectivity and treat it simply as one way

69. This reconstruction has analogues in the utopian program mentioned above, see note 39 supra, and would begin to deal with the problem of language to which Wittgenstein directed our attention, see p. 1217 supra. 
among many others to talk about human problems subject to the distortions of communication that characterize all of our activities. ${ }^{70}$

The second course is grounded in the hope, which is shared by many contemporary social theorists, that the contrast between subjectivity and objectivity is only a dilemma within the framework of liberal theory and can be transcended when some other currently ill-defined theory is developed. ${ }^{71}$ The odds of that hope being well-founded are greater, I think, than the odds that the problems can be resolved within liberal theory. But the chances that it is well-founded seem less than even. That estimate leads to the final possible responses to the argument I have made. Legal scholars can devote themselves to replaying the Realist line each time someone comes up with some clever but, the chances are, unfounded way around Realism's critique of the rule of law. The work of Professor Leff is my example. ${ }^{72}$ Finally, they can continue to do conventional legal scholarship, knowing that its premises are unsupported and indeed insupportable, precisely because it makes no less sense than anything else in the world. There is an intellectual tradition here too. For my purposes I can say that it begins with Kierkegaard.

70. See, e.g., Habermas, Toward a Theory of Communicative Competence, in REcENT Sociolocy No. 2, at 114 (H. Dreitzel ed. 1970).

71. See, e.g., A. Gmdens, Central Problems of Sociar Theory 2-7 (1979); R. Ungzr, supra note 11, at 236-95.

72. See Leff, Economic Analysis of Law: Some Realism About Nominalism, 60 VA. I. REv. 451 (1974); Leff, Unspeakable Elhics, Unnatural Law, 1979 DuxE L.J. 1229; Leff, Memorandum (Book Review), 29 STAN. L. REv. 879 (1977) (review of R. UNGER, supra note 11). 